\title{
PENGEMBANGAN MEDIA PEMBELAJARAN INTERAKTIF TEKNIK LISTRIK DAN ELEKTRONIKA BERBASIS LECTORA INSPIRE 17
}

\author{
A. Puri Laksani ${ }^{1}$, I G. Ratnaya ${ }^{2}$, I P. Suka Arsa $^{3}$ \\ ${ }^{1,2,3}$ Prodi Pendidikan Teknik Elektro, Universitas Pendidikan Ganesha, Singaraja \\ e-mai: pandeadipuri07@gmail.com, gede.ratnaya@undiksha.ac.id, suka.arsa@undiksha.ac.di
}

\begin{abstract}
Abstrak
Penelitian ini merupakan jenis penelitian research and development (R\&D) dan menggunakan model pengembangan ADDIE (analisis, desain, pengembangan, implementasi, evaluasi). Tujuan dari penelitian ini yaitu 1) Untuk mengetahui kelayakan media, 2) Untuk mengetahui respon siswa terhadap media. Hasil validasi dari ahli media (dosen) dan ahli materi (guru) diperoleh hasil validasi 1) ahli media (dosen) 85,29\% dengan kualifikasi sangat layak, 2) ahli materi (guru) 91,67\% dengan kualifikasi sangat layak serta untuk mengetahui respon siswa maka dilakukan uji lapangan dengan sasaran kelas X TAV dengan hasil 1) uji kelompok kecil 91,16\% dengan kualifikasi sangat layak, 2) uji kelompok besar $88,56 \%$ dengan kualifikasi sangat layak. Berdasarkan hasil analisis data penelitian, media interaktif teknik listrik dan elektronika berbasis lectora inspire 17 layak dan bisa digunakan oleh guru maupun siswa untuk proses belajar mengajar pada siswa kelas X TAV di SMK Negeri 3 Singaraja.
\end{abstract}

Kata Kunci: Media pembelajaran interaktif, Lectora Inspire 17, Teknik Listrik dan Elektronika

\begin{abstract}
Abstact
This research is a type of research and development $(R \& D)$ research and uses the ADDIE development models (analyze, design, development, implementation, evaluation). The purpose of this study is 1) To find out the feasibility of media, 2) To find out students' responses to the media. Validation results from media experts (lecturers) and material experts (teachers) obtained validation results 1) media experts (lecturers) $85.29 \%$ with very decent qualifications, 2) material experts (teachers) $91.67 \%$ with very decent qualifications and for knowing the response of students then conducted a field test with the target class X TAV with the results 1) small group test $91.16 \%$ with very decent qualifications, 2) large group test $88.56 \%$ with very decent qualifications. Based on the results of research data analysis, the interactive media of lectora inspire 17-based electrical and electronic engineering is feasible and can be used by teachers and students for the teaching and learning process in TAV class $X$ students at Vocational High 3 School Singaraja.
\end{abstract}

Keywords: Interactive learning media, Lectora Inspire 17, Electrical and Electronics Engineering

\section{Pendahuluan}

Berdasarkan observasi yang dilakukan di kelas X TAV SMK Negeri 3 Singaraja, yang dilakukan wawancara dan need assessment dengan guru pengajar mata pelajaran Teknik Listrik dan Elektronika yaitu guru menggunakan media terpisah berbasis Auoplay untuk mata pelajaran Dasar Teknik Elektronika dan Adobe Flash untuk mata Pelajaran Dasar Teknik Listrik dengan cara 1 arah (teacher center).

Oleh karena hal tersebut guru kurang mampu menyampaikan materi dengan baik kepada siswa sehingga berdampak saat siswa tersebut memasuki jenjang kelas XI masih belum memahami materi dasar akibat dari minat belajar siswa yang rendah sulitnya memahami materi. Seuai dengan kurikulum 2013 yang di perbaharui 2016 maka kedua mata pelajaran tersebut menjadi satu yakni menjadi mata pelajaran Teknik Listrik dan Elektronika, hal ini mengakibatkan guru kesulitan dalam memperbaharui media yang ada dan guru memerlukan media yang mudah dikembangkan kembali serta media yang mampu membantu guru menyampaikan materi (teacher center) dan membantu siswa dalam belajar mandiri (student center). 
Berdasarakan hal tersebut perlunya pengembangan media pembelajaran salah satunya seperti menggunakan software lectora inspire dan dalam hal ini guru di TAV masih belum ada yang mengembangkan media dengan menggunakan software ini. Lectora inspire dapat mengintegrasikan berbagai tipe media seperti gambar, suara, video, teks, animasi, test interaktif dengan berbagai format menjadi satu kesatuan yang membentuk media pembelajaran yang menarik serta dalam pengembangannya akan berisi minigame dan pembuatan bahannya didukung dengan bahan yang bisa diakses di internet, software photoshop, coreldraw, software program video editing dan sound recorder, serta software ini sudah dilengkapi tiga fitur diantaranya Camtasia for lectora yaitu aplikasi untuk merekam aktifitas pada layar kerja komputer, Snagit for lectora yaitu aplikasi yang mampu menciptakan potret layar kerja dengan resolusi yang tinggi, dan aplikasi animasi Flash. Dengan kelebihan tersebut akan menjadikan lectora inspire media pembelajaran yang menarik, dan mudah dipahami siswa serta mudah digunakan oleh guru.

Media pembelajaran terdiri dari dua suku kata yakni media dan pembelajaran. Secara harafiah, media berarti perantara atau pengantar, "Media adalah perantara atau pengantar pesan dari pengirim ke penerima pesan" Sadiman, dkk (1993:6). Menurut Sadiman, dkk (dalam Gusdanela 2014) mengatakan bahwa media (bentuk jamak dari kata medium), merupakan kata yang berasal dari bahasa latin medius, yang secara harfiah berarti 'tengah', 'perantara' atau 'pengantar'. Oleh karena itu, media dapat diartikan sebagai perantara atau pengantar pesan dari pengirim ke penerima pesan. Media dapat berupa sesuatu bahan (software) dan/atau alat ( hardware).Sedangkan menurut Undang- Undang Sistem Pendidikan Nasional No. 20 Tahun 2003 menyatakan pembelajaran adalah "proses interaksi peserta didik dengan pendidik dan sumber belajar pada suatu lingkungan belajar". Pembelajaran sebagai proses belajar yang dibangun oleh guru untuk mengembangkan kreatifitas berpikir yang dapat meningkatkan kemampuan berpikir siswa, serta dapat meningkat-kan kemampuan mengkontruksikan pengetahuan baru sebagai upaya meningkatkan penguasaan yang baik terhadap materi pelajaran.

Jadi dari pemaparan diatas, dapat disimpulkan pengertian media pembelajaran yaitu suatu penghantar berupa alat maupun suatu bahan yang mampu menunjang proses interaksi anatar peserta didik dengan pendidik dan sumber belajar pada suatu lingkungan belajar. Martinis Yamin, 2007: 204 (dalam Sagita Fitriani 2014: 24) membagi media itu ke dalam tiga macam, yaitu suara, media bentuk visual dan media gerak. Media bentuk visual dibedakan lagi menjadi tiga pula, yaitu gambar visual, garis (grafis) dan simbol verbal.

Berdasarkan pendapat dari beberapa ahli megenai jenis media pembelajaran diatas, maka peneliti menyimpulkan bahwa media pembelajaran terdiri dari 4 jenis yang diantaranya yaitu media cetak (buku, modul, dan media cetak lainnya), media dengan audio (disampaikan langsung oleh guru, rekaman, dan sebagainya), media dengan komputer (persentasi, serta pemanfaatan komputer sebagai media), media dengan pemanfaatan lingkungan (pengalaman langsung). Keempat jenis media tersebut dapat digunakan sekaligus. Pemilihan media yang tepat dapat memberikan suasana belajar yang nyaman bagi siswa serta memudahkan bagi siswa untuk memahami materi ajar.

Materi pelajaran atau bahan pelajaran (learning materials) adalah apa yang terdapat pada kurikulum yang telah diterapkan yang tertuang dalam Kompetensi Dasar (KD) yang harus dikuasai oleh setiap siswa dalam satuan pendidikan. Menurut Wina Sanjaya (2008:142) materi pelajaran dapat dibedakan menjadi: pengetahuan (knowledge), keterampilan (skill), dan sikap (attitude). Pengetahuan menunjuk pada informasi yang disimpan dalam pikiran ( $\operatorname{mind}$ ) siswa, dengan demikian pengetahuan berhubungan dengan berbagai informasi yang harus dihafal dan dikuasai oleh siswa, sehingga manakala diperlukan siswa dapat mengungkapkan kembali.

Keterampilan (skill) menunjuk pada tindakan - tindakan (fisk-non fisik) yang dilakukan seseorang dengan cara yang kompeten untuk mencapai tujuan tertent. Sikap menunjuk pada kecenderungan seseorang untuk bertindak sesuai dengan nilai dan norma yang diyakini kebenarannya oleh siswa. Merril 1997 (dalam Wina Sanjaya 2008:142) membedakan isi (materi 
pelajaran menjadi empat macam yaitu: fakta, konsep, prosedur, dan prinsip.

Fakta adalah sifat dari suatu gejala, peristiwa, benda, yang wujudnya dapat ditangkap oleh pancaindra. Fakta merupakan pengetahuan yang berhubungan dengan data-data spesifik (tunggal) baik yang telah maupun yang sedang terjadi yang dapat diuji atau diobservasi. "Ibu kota Indonesia adalah Jakarta", merupakan suatu fakta, karena memang pada kenyataannya demikian. Fakta merupakan materi pelajaran yang paling sederhana, karena materi ini sifatnya hanya mengingat hal - hal yang spesifik.

Konsep adalah abtraksi kesamaan atau keterhubungan dari sekelompok benda atau sifat. Suatu konsep memiliki bagian yang dinamakan atribut. Atribut adalah karakteristik yang dimiliki suatu konsep. Gabungan dari berbagai atribut menjadi suatu pembeda antara satu konsep dengan konsep lainnya. Contoh, anak laki - laki merupakan suatu konsep yang memiliki atribut tertentu yang berbeda dengan atribut yang dimiliki oleh konsep "anak perempuan". Dengan demikian, pemahaman tentang konsep harus didahului dengan pemahaman tentang data dan fakta, sebab atribut itu sendiri pada dasarnya adalah sejumlah fakta yang terkandung dalam objek.

Prosedur adalah materi pelajaran yang berhubungan dengan kemampuan siswa untuk menjelaskan langkah-langkah secara sistematis tentang sesuatu. Misalnya, prosedur tentang langkah-langkah melakukan suatu percobaan, langkah-langkah membuat suatu karangan, dan lain sebagainya.

Hubungan antara dua atau lebih konsep yang sudah teruji secara empiris dinamakan generalisasi yang selanjutnya dapat ditarik ke dalam prinsip. Contoh prinsip tentang ketertiban lalu lintas, prinsip tentang kesejahterahan sosial, prinsip tentang penguapan, prinsip tentang radiasi dan sebagainya. Materi pelajaran tentang prinsip akan lebih sulit dibandingkan dengan fakta, atau konsep. Sebab, seseorang akan dapat menarik suatu prinsip apabila sudah memahami berbagai fakta dan konsep yang relevan.

Pembelajaran konvensinal, guru sering menentukan buku teks sebagai sebagai satusatunya sumber materi pelajaran. Perubahan dan penyempurnaan kurikulum dapat membuat perubahan buku ajar. Akibatnya, ketika terjadi perubahan kurikulum, maka selalu diikuti oleh perubahan buku pelajaran. Maka dari itu sumber bahan pelajaran tidak hanya buku ajar tetapi juga sumber lainnya Wina Sanjaya (2008:146): misalnya menggunakan jurnal yang menyajikam berbagai pengetahuan mutakhir, majalah, Koran dan sumber informasi elektronik, misalnya dengan menggunakan dan memanfaatkan internet dan lain sebagainya. Kemajuan teknologi informasi, memungkinkan materi pelajaran tidak hanya disimpan dalam buku teks saja, akan tetapi bisa disimpan dalam berbagai bentuk teknologi yang lebih efektif dan efisien, misalnya dalam bentuk CD, kaset, dan lain sebagainya. Dalam bentuk-bentuk semcam ini diyakini materi pelajaran akan lebih menarik untuk dipelajari sebab dengan berbagai teknik animasi, maka materi pelajaran akan lebih jelas dan konkret. Sesuatu yang tidak mungkin disajikan dalam buku cetak karena keterbatasannya, mak dalam bentuk media elektronik akan dapat disajikan.

Tuntutan kurikulum seperti pada Kurikulum Tingkat Satuan Pendidikan (KTSP), menuntut siswa agar tidak hanya sekedar menguasai nformasi teoritis, akan tetapi bagaimana informasi tersebut dapat dikembangkan sesuai dengan kebutuhan daerah dan lingkungan dimana siswa tinggal. Dengan demikian kehidupan masyarakat nyata mestinya dijadikan sebagai salah satu bahan pelajaran.

Sumber materi pelajaran yang dapat dimanfaatkan untuk proses pemelajaran dapat dikategorikan sebagai berikut: 1) Tempat atau lingkungan, 2) Orang atau narasumber, 3) Objek, 4) Bahan cetak dan noncetak. Jadi sumber materi ajar tidak hanya bersumber dari buku teks tetapi juga dapat dari sumber lainnya misalkan dari sumber elektronik, lingkungan, narasumber, objek, maupun bahan cetak atau non cetak.

Arsyad (2007:170) Multimedia dikenal berbagai macam kombinasi grafik, teks, suara, video dan animasi. Penggabungan ini merupakan suatu kesatuan yang secara bersama-sama menampilkan informasi, pesan atau isi pelajaran. Jadi Multimedia interaktif adalah suatu multimedia yang dilengkapi dengan alat pengontrol yang dapat dioperasikan oleh pengguna, 
sehingga pengguna dapat memilih apa yang dikehendaki untuk proses selanjutnya atau merupakan perpaduan antara berbagai media (format file) yang berupa teks, gambar, grafik, sound, animasi, video interaksi, dll yang telah dikemas menjadi file digital (komputerisasi), digunakan untuk menyampaikan pesan kepada publik. Multimedia interaktif adalah suatu multimedia yang dilengkapi dengan alat pengontrol yang dapat dioperasikan oleh pengguna, sehingga pengguna dapat memilih apa yang dikehendaki untuk proses selanjutnya (Daryanto, 2013).

Lectora merupakan Authoring Tool untuk pengembangan konten e-learning yang dikembangkan oleh Trivantis Corporation (Muhamad Mas'ud, (dalam Sagita Fitriani 2016:32)). Lectora ${ }^{\circledR}$ Inspire mampu membuat kursus online cepat dan sederhana. Pendiri dari Lectora® Inspire adalah Timothy D. Loudermilk di Cincinnati, Ohio, Amerika tahun 1999. Seperti software authoring tool pada umumnya, Lectora Inspire juga membutuhkan spesifikasi system minimal. Sebagai authoring tool yang tengah banyak dikembangkan, Lectora Inspire memiliki beberapa kelebihan dibanding authoring tool e-learning lainnya.

Menurut Sugiyono (2010:297) penelitian dan pengembangan (reseach and development) adalah metode penelitian dengan tujuan untuk menghasilkan produk tertentu dan menguji keefektifan produk tersebut. Model penelitian ADDIE merupakan singkatan dari Analysis, Design, Development, Implementation, dan Evaluation. Model ini dikembangkan oleh Dick and Carey pada tahun 1996. Berdasarkan urian tersebut dan merujuk dari pemaparan permasalahan maka peneliti melakukan pengembangan media pembelajaran dengan judul "Pengembangan Media Pembelajaran Interaktif Teknik Listrik dan Elektronika Berbasis Lectora Inspire 17".

\section{Metode}

Jenis penelitian ini adalah R\&D yaitu Reseach and Development. Menurut Sugiyono (dalam Sagita F., 2014: 42) metode penelitian dan pengembangan merupakan metode penelitian yang digunakan untuk menghasilkan produk tertentu, dan menguji keefektifan produk tersebut. Sedangkan Model penelitian yang digunakan adalah model penelitian ADDIE, sehingga pada penelitian dan pengembangan ini terdapat 5 tahap yaitu analysis, design, development, implementation and evaluation.

Pada tahap analisis adapun yang dilakukan adalah mencari dan mengumpulkan data pendukung untuk pengembangan media yang dibuat. Tahap desain (perancangan), media yang dibuat disesuaikan dengan data pada tahap analisis. Tahap pengembangan mewujudkan media yang telah dirancang atau didesain sebelumnya dalam bentuk output berupa CD (Compact Disk) ataupun berupa softcopy yang dapat dibuka tanpa aplikasi pembuatnya pada PC ataupun smartphone. Tahap selanjutnya yaitu tahap implementasi mewujudkan ide-ide pengembangan diatas dengan media yang nyata. Dan yang terakhir yaitu tahap evaluasi yang dimaksudkan adalah menguji cobakan media pada subjek uji coba yang dilakukan oleh orang- orang yang memiliki pengetahuan, pengelaman, dan pemahaman dalam desain media (dosen) dan materi pada media (guru pengampu mata pelajaran) tersebut serta yang akan menjadi sasaran penggunaan media tersebut dengan melakukan uji perorangan, uji coba kelompok kecil dan uji coba kelompok besar.

Penelitian pengembangan ini dilakukan di SMK Negeri 3 Singaraja dengan sasaran uji coba yaitu kelas X TAV dengan jumlah sasaran 30 orang. Jenis data yang digunakan pada penelitian dan pengembangan ini yaitu dengan jenis data kuantitatif, yang dimana data kuantitatif didapatkan dari hasil pengisian kuisioner dari ahli materi dan ahli media. Kemudian hasil data yang diperoleh melalui angket atau kuisioner yang diberikan oleh peneliti diteruskan dengan pengolahan data menggunakan rumus-rumus statistika secara manual menggunakan komputer.

Untuk mengukur kelayakan media yang dibuat menggunakan teknik pengumpulan data dengan interview, kuisioner (angket), dan observasi. Dalam penelitian ini instrument yang digunakan adalah 1) Lembar validasi media pembelajaran digunakan untuk mengetahui sejauh mana kualitas media yang dihasilkan sebagai media layak untuk diuji cobakan, 2) Lembar validasi materi digunakan untuk mengetahui sejauhmana kelengkapan isi materi yang disajikan 
berdasarkan pedoman silbus, sehingga media ini layak diberikan kepada siswa, 3) Lembar angket atau kuisioner berfungsi untuk menegtahui keefektifannya setelah menggunakan media yang baru pada sasaran uji coba yaitu kelas X TAV.

Beberapa kriteria seperti sangat setuju (SS), setuju (S), tidak setuju (TS), serta sangat tidak setuju (STS) dijabarkan berdasarkan data kualitatif berdasarkan skor penilaian instrument para ahli serta uji coba kelompok kecil dan uji coba kelompok besar. Menurut Sukardi (2003:146147) untuk menskor skala kategori likert, jawaban diberi bobot atau disamakan dengan nilai kuantitatif 4 (kategori Sangat Setuju/SS), 3 (kategori Setuju/S), 2 (kategori Tidak Setuju/TS), 1 (kategori Sangat Tidak Setuju/STS), untuk empat pilihan pernytaan positif. Dan 1 (kategori Sangat Setuju/SS), 2 (kategori Setuju/S), 3 (kategori Tidak Setuju/TS), 4 (kategori Sangat Tidak Setuju/STS) untuk pernyataan bersifat negatif. Pernyataan negatif disisipkan pada pernyataan positif untuk mengukur keseriusan jawaban responden untuk memberikan respon. Berdasarkan data kualitatif skor penilaian untuk instrument validasi uji ahli media dan uji validasi ahli materi serta untuk instrument uji coba kelompok kecil dan uji coba kelompok besar. Kemudian untuk menganalisis data kuantitatif yang diperoleh melalui angket menggunakan 2 rumus, selanjutnya diolah dengan cara dibuat persentase dengan rumus analisis per item sebagai berikut:

$$
\mathrm{P}=\frac{\pi}{\pi \mathrm{i}} \mathrm{x} 100 \%
$$

(untuk uji validasi ahli media dan uji validasi ahli materi), dan

$$
\mathrm{P}=\frac{2 x}{\sum x i} \times 100 \%
$$

(untuk uji sasaran uji coba)

$$
\begin{aligned}
& \text { Keterangan: } \\
& \mathrm{P}=\text { Persentase Kelayakan } \\
& x=\text { Nilai Jawaban Penilaian } \\
& \begin{array}{ll}
\sum x \quad=\text { Jumlah Jawaban Penilaian } \\
x i & =\text { Nilai Jawaban Tertinggi } \\
\sum_{x i} x i & =\text { Jumlah Nilai Jawaban Tertinggi } \\
100 & =\text { Bilangan Konstan }
\end{array}
\end{aligned}
$$

Penentuan kriteria kualifikasi tingkat kelayakan penilaian berdasarkan presentase supaya pembacaan hasil penelitian menjadi lebih mudah maka dilakukan dengan cara sebagai berikut:

1. Menentukan persentase skor ideal (maksimal) $=100 \%$

2. Menentukan presentase skor rendah (minimum) $=0 \%$

3. Menentukan range $=100-0=100$

4. Menentukan kelas interval, yaitu 4 (Sangat Layak, layak, kurang layak, tidak layak)

5. Menentukan lebar interval $=(100 \% / 4 \%=25)$

Tabel 1. Kualifikasi Tingkat Kelayakan Berdasarkan Persentase (Sumber: Arikunto dalam (Ahmad Fauzan, 2011:34-35))

\begin{tabular}{ccc}
\hline Persentase Pencapaian & Skala Nilai & Interprestasi \\
\hline $76 \% \leq$ skor $\leq 100 \%$ & 4 & Sangat Layak \\
$51 \leq$ skor $\leq 75 \%$ & 3 & Layak \\
$26 \% \leq$ skor $\leq 50 \%$ & 2 & Cukup Layak \\
$0 \% \leq$ skor $\leq 25 \%$ & 1 & Kurang Layak \\
\hline
\end{tabular}

Apabila skor validasi yang diperoleh minimal $51 \%$ maka media pembelajaran yang dikembangkan tersebut sudah dapat dimanfaatkan sebagai media pembelajaran dalam kegiatan 
belajar mengajar di sekolah.

\section{Hasil dan Pembahasan}

Pada penelitian ini adapun hasil yang didapatkan dari model penelitian ADDIE yaitu sebagai berikut:

1) Analysis: Pada tahap analisis ini adapun yang dilakukan adalah mencari dan mengumpulkan data pendukung untuk pengembangan media yang dibuat. Adapun hasil dari proses analysis ini yaitu 1a) Data lapangan dari hasil observasi yang dimana siswa mengalami penurunan minat belajar karena kegiatan belajar mengajar cenderung berpusat pada guru (teacher center). 1b) Adanya pembaharuan kurikulum yang membuat mata pelajaran berubah serta materi yang diberikan juga berubah. 1c) Dari analisis silabus mata pelajaran Teknik Listrik dan Elektronika terdapat $4 \mathrm{KD}$ dasar yang sulit dipahami siswa, sehingga media yang dibuat terdiri dari $4 \mathrm{KD}$ tersebut dalam satu media yang diantaranya adalah sebagai berikut: a) KD 3.1 Memahami besaran dari "SI units" pada kelistrikan; b) KD 3.2 Membedakan spesifikasi data komponen listrik; c) KD 3.3 Memahami hukum - hukum kelistrikan dan elektronika; dan d) KD 3.4 Menjelaskan pemakaian alat - alat ukur listrik.

2) Design: Pada tahap design (perancangan), media yang dibuat disesuaikan dengan data pada tahap analisis. Media pembelajaran dengan software Lectora Inspire 17 didesain dengan memiliki fitur media berupa musik, video, gambar, animasi, game interaktif yang mendukung materi mata pelajaran teknik listrik dan elektonika. Serta memiliki tampilan yang jelas, menarik dan didukung dengan bahasa yang baik.

3) Development: Pada tahap ini mewujudkan media yang telah dirancang atau didesain sebelumnya dalam bentuk output berupa $C D$ (Compact Disk) ataupun berupa softcopy yang dapat dibuka tanpa aplikasi pembuatnya pada $P C$. Media dalam bentuk $C D$ ini yang akan diberikan kepada pihak sekolah untuk selanjutnya dapat dipergunakan sebagai alternatif media bantu belajar mengajar.

4) Implementation: Pada tahap implementation (implementasi) yang merupakan tahap yang dimaksudkan adalah mewujudkan ide-ide pengembangan diatas dengan media yang nyata. Seperti yang terlihat pada gambar yang telah dibuat secara nyata dari yang telah didesain.

5) Evaluation: Pada tahap evaluation (evaluasi) yang merupakan tahap terakhir dari model peelitian ini. Pada tahap ini dimaksudkan adalah menguji cobakan media yang dibuat dan pengujian media.

Data uji coba produk pengembangan media pembelajaran dilakukan dalam tiga tahap. Tahap pertama diperoleh dari hasil penilaian terhadap produk pengembangan media pembelajaran yang dilakukan oleh Dosen ahli media pembelajaran. Tahap kedua diperoleh dari hasil penilaian terhadap produk pengembangan media pembelajaran yang dilakukan oleh guru pengampu mata pelajaran Teknik Listrik dan Elektronika kelas X TAV sebagai ahli materi. Tahap ketiga uji coba produk ke sasaran uji coba yaitu siswa kelas X TAV di SMK Negeri 3 Singaraja. Data yang diperoleh merupakan data kuantitatif dimana data kuantitatif diperoleh dari angket penilaian respon siswa.

Hasil validasi uji ahli media diperoleh dengan menggunakan angket pada media pembelajaran multimedia interaktif ini yang dimuat dalam 17 item pertanyaan yang harus dijawab oleh dosen ahli media. Pada angket yang telah diisi oleh dosen ahli media atas nama Bapak Prof. Dr. I Made Candiasa M.I.,Komp., rerata persentase dari uji validasi ahli media yaitu 85,29\% dan setelah dikonversikan ketabel tingkat pencapaiannya maka respon siswa dalam uji perorangan ini berada dalam kualifikasi sangat layak,

Hasil validasi uji ahli materi diperoleh dengan menggunakan angket pada media pembelajaran multimedia interaktif ini yang dimuat dalam 15 item pertanyaan yang harus dijawab oleh guru pengampu mata pelajaran teknik listrik dan elektronika. Pada angket yang telah diisi oleh guru atas nama Bapak I Wayan Adi Perbawa S.Pd., M.Pd., rerata persentase dari uji perorangan yaitu $91,67 \%$ dan setelah dikonversikan ketabel tingkat pencapaiannya maka respon siswa dalam uji perorangan ini berada dalam kualifikasi sangat layak. 
Setelah melaksanakan uji validasi media dan materi serta memperbaiki media sesuai dengan revisi para ahli maka dilanjutkan dengan mencari hasil uji coba produk pada sasaran uji coba diantaranya: 1) tahap uji kelompok kecil media diuji coba dengan 10 perwakilan siswa yang dipilih secara acak untuk mewakili karakteristik populasi sasaran, rerata persentase dari uji perorangan yaitu $91,16 \%$ dan setelah dikonversikan ketabel tingkat pencapaiannya maka respon siswa dalam uji kelompok kecil ini berada dalam kualifikasi sangat layak, dan yang terakhir 2) tahap uji kelompok besar ini media diuji coba terlebih dahulu dengan 30 perwakilan siswa yang dipilih secara acak untuk mewakili karakteristik populasi sasaran, rerata persentase dari uji perorangan yaitu $88,56 \%$ dan setelah dikonversikan ketabel tingkat pencapaiannya maka respon siswa dalam uji perorangan ini berada dalam kualifikasi sangat layak.

Penelitian ini dilakukan untuk mengetahui bagaimana mengembang-kan media pembelajaran interaktif berbasis lectora inspire 17 untuk mata pelajaran teknik listrik dan elektronika pada siswa kelas X TAV di SMK Negeri 3 Singaraja.

Berdasarkan hasil analisis dari angket tanggapan dosen dan guru terhadap media pembelajaran ini, menunjukkan bahwa media pembelajaran interaktif teknik listrik dan elektronika berbasis lectora inspire 17 layak digunakan sebagai alat bantu pembelajaran pada mata pelajaran teknik listrik dan elektronika dan sesuai dengan konsep materi yang ada pada media sesuai dengan konsep materi yang ada pada silabus. Ahli media memberikan nilai 85,29\% (sangat layak) sedangkan guru pengampu mata pelajaran memberikan nilai $91,67 \%$ (sangat layak) pada aspek materi.

Berdasarkan rumusan masalah dari hipotesis, mka dapat disimpulkan bahwa hipotesis diterima, yang artinya pengembangan media pembelajaran interaktif teknik listrik dan elektronika berbasis lectora inspire 17 dapat dikatakan layak. Hal ini menunjukkan pengembangan media ini sudah dapat digunakan untk media bantu guru dalam menyampaikan materi di dalam kelas maupun di luar kelas. Selain itu setelah melaksakan uji coba lapangan maka didapatkan melau angket respon siswa bahwa media pembelajaran dapat digunakan sebgai media bantu dalam pembelajaran teknik listrik dan elektronika.

Berdasarkan hasil dari angket tanggapan dosen terhadap media pembelajaran ini, dapat diketahui kelebihan-kelebihan dari media yang diantaranya sebagai berikut:

a. Media dapat digunakan dengan mudah

b. Tampilan dari warna, gambar, suara, dan video menarik

c. Terdapat game yang dapat mengatasi kebosanan siswa

d. Terdapat test akhir yang dapat menegtahui dan mengevaluasi hasil belajar siswa

Berdasarkan hasil angket tanggapan dosen terhadap media dapat diketahui kekurangankekurangan dari media pembelajaran yaitu tombol navigasi pada menu utama masih ambigu dan harus dibuat secara terintegrasi.

\section{Simpulan dan Saran}

Media interaktif teknik listrik dan elektronika berbasis lectora inspire 17 layak dan bisa digunakan oleh guru maupun siswa untuk proses belajar mengajar pada siswa kelas X TAV di SMK Negeri 3 Singaraja. Hasil uji coba media pembelajaran berbasis lectora inspire 17 ini yaitu hasil persentase dari validasi ahli media $85,29 \%$ (sangat layak), hasil persentase dari validasi ahli materi $91,67 \%$ (sangat layak), serta hasil uji coba lapangan diperoleh hasil yaitu 1) uji coba perorangan memperoleh persentase $89,44 \%$ yang diperoleh dari tanggapan 3 orang siswa, 2) uji coba kelompok kecil memperoleh $91,16 \%$ yang diperoleh dari 10 orang siswa, 3) uji coba lapangan yang menggunakan 30 siswa memperoleh hasil 88,56\%.

Berdasarkan penelitian yang telah dilakukan, dapat disampaikan saran yang berkaitan dengan pengembangan media pembelajaran berbasis lectora inspire 17 yaitu saran bagi guru sebagai pendidik diharapkan dapat berinovasi dan berkreasi untuk mengembangkan media pembelajaran dan pengembangan media pembelajaran interaktif berbasis lectora inspire 17 ini diterapkan lebih lanjut agar siswa tertarik dan lebih termotivasi dalam belajar. Media pembelajaran multimedia interaktif ini diharapkan dapat digunakan sebagai saran belajar 
sebelum menggunakan peralatan sesungguhnya.

Saran bagi siswa Saran bagi siswa diharapkan siswa mampu menguasai materi yang terdapat dalam media pembelajaran dan siswa juga menggunakan media pembelajaran interaktif berbasis lectora inspire 17 dijadikan sebagai salah satu refrensi dalam memahami materi mata pelajaran teknik listrik dan elektronika Saran bagi peneliti berikutnya, Saran bagi peneliti berikutnya, diharapkan dengan adanya media pembelajaran interaktif berbasis lectora inspire 17 untuk materi pada mata pelajaran teknik listrik dan elektronika ini dapat memicu kreatifitas untuk membuat suatu karya yang bermanfaat langsung bagi guru maupun siswa untuk membantu dalam meningkatkan kualitas pembelajaran. Peneliti juga agar lebih teliti dalam pemaparan materi agar lebih konsisten dan sesuaikan bahasan EYD, pemilihan warna serta gambar yang menarik dan tidak kontras juga akan dapat mempengaruhi minat belajar siswa.

\section{Daftar Pustaka}

Arsyad, A. 2007. Media Pembelajaran. Jakarta: PT Rajagrafindo Persada. Daryanto. 2013. Media Pembelajaran Peranannya Sangat Penting Dalam Mencapai Tujuan Pembelajaran. Yogyakarta: Gava Media.

Fauzan, A. 2011. "Analisis Kelayakan Media Pembelajaran Perakitan Komputer Untuk Siswa Sekolah Menengah Kejuruan". Skripsi. Program Studi Pendidikan Teknik Elektronika, Fakultas Teknik, Universitas Negeri Yogyakarta.

Fitriani, S. 2014. "Pengembangan Media Pembelajaran Menggunakan Program Lectora Dengan Materi Proses Pembentukan Muka Bumi Untuk Siswa SMP Kelas VII". Skripsi. Jurusan Pendidikan IImu Pengetahuan Sosial, Universitas Negeri Yogyakarta.

Gusdanela. "Pengertian Media Menurut Beberapa Ahli dan Perbedaan Media Pembelajaran dengan Sumber Belajar" dalam http://gusdanela.blogspot.com/2014/02/pengertian-mediamenurut-beberapa-ahli.html diakses tanggal 30 Januari 2019.

Hasanah, N, dkk. 2015. "Pengembangan Media Pembelajaran Berbasis Lectora Inspire Pada Pokok Bahasan Struktur Atom dan Sistem Periodik Unsur Untuk Kelas X SMA/MA" Program Studi Pendidikan Kimia (hlm. 2).

Hasanah, Nurul, dkk (2015) "Pengembangan Media Pembelajaran Berbasis Lectora Inspire Pada Pokok Bahasan Struktur Atom dan Sistem Periodik Unsur Untuk Kelas X SMAMA" (hlm 4).

Hikmah, U, N. 2016. "Media Video Pembelajaran Globalisasi untuk Meningkatkan Hasil Belajar PKn (studi kasus: siswa Kelas IV SDN Purwoyoso 01 Semarang)". Skripsi. Jurusan Pendidikan Guru Sekolah Dasar, Universitas Negeri Semarang.Jakarta: Kharisma Putra Utama.

Laili Saadah, Nur, dkk (2016) "The Development of Accounting Learning Media Using Lectora Inspire in Financial Statement Topic of Grade X at SMK Negeri 1 Malang" Volume 1 (hlm 57).

Mas'ud, M. 2012. Membuat Media Pembelajaran dengan Lectora. Yogyakarta: Shonif. 
Nurrochim, Y. 2013. "Media Pembelajaran Berbasis Multimedia Komputer Untuk Materi Komponen Elektronika Pada Siswa Kelas VII di SMP Negeri 3 Pedan Kabupaten Klaten". Tugas Akhir, Fakultas Teknik, Universitas Negeri Malang.

Sadiman, A, dkk. 1993. Media Pendidikan: Pengertian Pengembangan dan Pemanfaatannya. Jakarta: Rajagrafindo Persada.

Sadiman, A, dkk. 2009. Media Pendidikan Pengertian, Pengembangan dan Pemanfaatannya. Jakarta: PT Rajagrafindo Persada.

Sanjaya, S, dkk. 2017 "Penerapan Media Pembelajaran Lectora Inspire Untuk Meningkatkan Minat dan Prestasi Belajar Perhitungan Konstruksi Mesin Siswa Kelas XI Mesin di SMK Piri Sleman". Program Studi Teknik Mesin, Volume 5, Nomor 1 (hlm. 56).

Sanjaya, W. 2008. Perencanaan dan Desain Sistem Pembelajaran. Jakarta: Prenadamedia Group.

Sellyna, N, dkk. 2016 "Pengembangan Lectora Inspire Sebagai Multimedia Interaktif Pembelajaran Kimia Pada Pokok Bahasan Hidrolisis Garam di SMA/MA". Program Studi Pendidikan Kimia (hlm. 2).

Sudaryono. 2016. Metode Penelitian Pendidikan. Jakarta: Prenadamedia Sugiyono. 2010. Metode Penelitian dan Pendidikan Kuantitatif, Kualitatif, dan R\&D. Bandung: Alfabeta.

Sugiyono. 2015. Metode Penelitian Kualitatif, kuantitatif, dan R\&D. Bandung: CV Alfabeta.

Sugiyono. 2015. Metode Penelitian Pendidikan. Bandung: CV Alfabeta. Sugiyono.2013. Metode Penelitian Kualitatif, Kuantitatif dan R\&D. Bandung: CV Alfabeta.

Sukamto, dkk. 2016. "Pembelajaran Matematika Menggunakan CD Interaktif AMT Berbasis Lectora Inspire Untuk Siswa SD" Pendidikan Guru Sekolah Dasar, Volume 3, Nomor 1 (hlm. 1).

Sukardi. 2003. Metedologi Penelitian Pendidikan Kompetensi dan Pratiknya. Jakarta: PT Bumi Aksara. 